\title{
Appropriate hydration period and chemical agent improve priming in brachiaria seeds ${ }^{1}$
}

\author{
Thiago Barbosa Batista ${ }^{2}$, Flávio Ferreira da Silva Binotti ${ }^{3}$, \\ Eliana Duarte Cardoso ${ }^{3}$, Edilson Costa ${ }^{3}$, Daniele Maria do Nascimento ${ }^{2}$
}

\section{ABSTRACT}

Priming is an alternative to improve the performance of seeds that have germination problems, such as Urochloa brizantha seeds. This study aimed at evaluating the appropriate hydration period and chemical agents used for priming, via direct immersion, in the physiological quality and carbohydrate content of $U$. brizantha seeds. The experimental design was completely randomized, in a $3 \times 4$ factorial arrangement, with four replicates of each treatment, consisting of lower, median and higher hydration periods, in the phase II of the absorption curve, and agents used for priming: water, gibberellin, sucrose and antioxidant (riboflavin). Germination and vigor tests were carried out, as well as carbohydrate contents determination, in the seeds. It was observed that seeds hydrated in the lower period show higher physiological potential. Priming with gibberellin provides a greater seedling emergence, and with sucrose higher carbohydrate contents.

KEY-WORDS: Urochoa brizantha; gibberellin; sucrose; riboflavin.

\section{INTRODUCTION}

Several forage grass species have been used for cattle pasture in Brazil. Among them, the Urochloa genus stands out due to its wide edaphoclimatic adaptability, high yield of dry phytomass and low plant health problems. Another important aspect of this genus is related to the high marketing of its seeds.

Brazil is the largest producer and exporter (40 countries) of tropical forage seeds in the world (Cardoso et al. 2014). However, some factors inherent to forage seeds, such as dormancy (Binotti et al. 2014) or production technology, limit the achievement of high quality seeds.

\section{RESUMO}

Período de hidratação e agente químico adequados beneficiam o condicionamento fisiológico em sementes de braquiária

O condicionamento fisiológico é uma alternativa para melhoria do desempenho de sementes que apresentam problemas de germinação, como é o caso das sementes de Urochloa brizantha. Objetivou-se estudar o período adequado de hidratação e agentes químicos empregados no condicionamento fisiológico, via imersão direta, na qualidade fisiológica e teor de carboidratos, em sementes de $U$. brizantha. O delineamento experimental utilizado foi o inteiramente casualizado, em esquema fatorial $3 \times 4$, com quatro repetições de cada tratamento, constituído por períodos de hidratação inferior, mediano e superior, na fase II da curva de absorção, e agentes empregados no condicionamento: água, giberelina, sacarose e antioxidante (riboflavina). Foram realizados testes de germinação e vigor, além de teor de carboidratos, nas sementes. Verificou-se que sementes hidratadas no período inferior apresentam maior potencial fisiológico. O condicionamento com giberelina propicia maior emergência de plântulas, e com sacarose maior teor de carboidratos.

PALAVRAS-CHAVE: Urochloa brizantha; giberelina; sacarose; riboflavina.

Priming is an alternative to improve the seeds quality. This technique consists of synchronizing and reducing the time of seed germination (Marcos Filho 2015) by controlled hydration, allowing the beginning of the physiological germination processes (phases I and II). Priming also avoids the issue of the radicle, which occurs in phase III (Lara et al. 2014). Hydropriming (direct immersion) is a viable priming technique (Soltani \& Soltani 2015), particularly in agricultural areas, due to easiness of execution.

The beneficial effect of priming germination has been reported for cotton (Oliveira et al. 2010, Queiroga et al. 2011), lentil (Toklu 2015), millet (Peske \& Novembre 2010) and sorghum (Oliveira \&

1. Manuscript received in Nov./2015 and accepted for publication in Sep./2016 (http://dx.doi.org/10.1590/1983-40632016v4638422).

2. Universidade Estadual Paulista "Júlio de Mesquita Filho", Faculdade de Ciências Agronômicas, Botucatu, SP, Brazil.

E-mails: batistatb@hotmail.com, daniele_ocz@hotmail.com.

3. Universidade Estadual de Mato Grosso do Sul, Cassilândia, MS, Brazil.E-mails: binotti@uems.br, elianaduarte@uems.br, mestrine@uems.br. 
Gomes-Filho 2010) seeds. Some authors have shown the benefits of priming in the Urochloa genus. Bonome et al. (2006) observed an increase in the root protrusion speed in $U$. brizantha seeds primed by soaking in aerated solution of $\mathrm{KNO}_{3}$, $\mathrm{PEG} 6000$, or a combination of them, for a period of $12 \mathrm{~h}$. Batista et al. (2016) found that the application of priming via direct immersion (hydration without aeration) of $U$. brizantha seeds for $2 \mathrm{~h}$ provides seeds with increased tolerance to artificial stress.

Information on the different periods of hydration via direct immersion without aeration, to establish the immersion time in the priming of seeds, are incipient for $U$. brizantha seeds, highlighting the need for studies in this area. The selection of the best priming agent is another crucial factor worth studying.

This study aimed at identifing the appropriate periods of hydration and suitable chemical agents for priming of $U$. brizantha seeds via direct immersion (hydration without aeration). The physiological quality of the seeds and their carbohydrate content were also evaluated.

\section{MATERIAL AND METHODS}

The experiment was conducted at the Universidade Estadual de Mato Grosso do Sul, in Cassilândia, Mato Grosso do Sul State, Brazil, between January and August 2014. U. brizantha (Brachiaria brizantha cv. MG-5) seeds from the 2013/2014 harvest were used. The initial physiological characteristics of the seeds were: water content $=14 \%$; first germination count $=2 \%$; total germination $=31 \%$; dormant seeds $=51 \%$; germination speed index $=0.89$.

Prior to the application of different treatments, the seeds were submitted to chemical scarification with concentrated sulphuric acid $\left(\mathrm{H}_{2} \mathrm{SO}_{4}\right)$, for $5 \mathrm{~min}$, to overcome physical dormancy. After that, the seeds were washed and placed in deionized running water and naturally dried for $24 \mathrm{~h}$.

The experiment was installed in a completely randomized design, in a $3 \times 4$ factorial arrangement, with four replicates of each treatment. The first factor consisted of three periods: lower, median and higher hydration, in the phase II of the absorption curve (Table 1). The second factor consisted of four different agents used in priming: water, gibberellin $\left(\mathrm{GA}_{3} ; 0.5 \mathrm{mg} \mathrm{L}^{-1}\right)$, sucrose $(10 \%)$ and antioxidant (riboflavin at $25 \mathrm{ppm}$ ).
Priming was carried out by hydration of seeds through direct immersion in $100 \mathrm{ml}$ of each tested solution, in plastic containers allocated in an incubation chamber, at $25^{\circ} \mathrm{C}$, without aeration. After priming, the seeds were dried at room temperature, for $24 \mathrm{~h}$.

The hydration periods were determined from the absorption curves for water, sucrose, riboflavin and gibberellin (Table 1). Three periods were established within the phase II of absorption for each curve: lower hydration period (after the start of phase II), median hydration period (at half of phase II) and higher hydration period (at the end of phase II).

After priming, the seeds were subjected to physiological tests and carbohydrate content determination.

The germination test was carried out with four subsamples of 50 seeds, distributed in plastic gerboxes, using as substrate blotting paper moistened with 2.5 times its mass. The counts were performed at 7 (first germination count) and 21 days (total germination) after sowing (Brasil 2009).

The germination speed index was calculated by the sum of the number of germinated seeds at each day, divided by the number of days between sowing and germination (adapted from Maguire 1962).

For accelerated aging, a single layer of seeds was placed on the metal screen coupled to the gerbox, containing $40 \mathrm{ml}$ of deionized water, and placed in a growth chamber for $72 \mathrm{~h}$, at $42{ }^{\circ} \mathrm{C}$. After the aging process, seeds were sown in germination boxes and the germination count was carried out at 7 days after the test installation (Brasil 2009).

Seeds remaining from the germination test (viable and unviable) were evaluated by the tetrazolium test, according to a standard methodology for Urochloa (Brachiaria) seeds (Brasil 2009), which consists of counting the number of viable (dormant) and unviable seeds remaining from the germination test.

Seedling emergence was conducted in a greenhouse, with four subsamples of 50 seeds. The seeds were sown in trays containing vermiculite.

Table 1. Hydration period established for each chemical agent.

\begin{tabular}{lccc}
\hline \multirow{2}{*}{ Substance } & \multicolumn{3}{c}{ Period $(\mathrm{h})$} \\
\cline { 2 - 4 } & Lower & Median & Higher \\
\hline Water & 3 & 8 & 13 \\
Sucrose & 4 & 9 & 13 \\
Riboflavin & 3 & 8 & 13 \\
Gibberellin & 5 & 10 & 14 \\
\hline
\end{tabular}


The percentage of emerged plants at 7 days (first emergency count) was recorded up to the stabilization of their emergence, with a limit at 28 day after sowing (total emergence). The results were expressed in percentage of seedling emergence.

The emergence speed index was calculated by the sum of the number of seedlings emerged at each day, divided by the number of days between sowing and emergence (adapted from Maguire 1962), up to the stabilization of the number of seedlings emerged, with a 28-days limit after sowing.

The dry phytomass of seedlings was randomly evaluated from 10 normal seedlings of each repetition from the emergence test. The seedlings were removed in a way that their root system was maintained intact, and subsequently washed and dried in a forced ventilation oven at $65^{\circ} \mathrm{C}$, for $72 \mathrm{~h}$. After drying, the samples were weighed in an analytical balance and values expressed in $\mathrm{mg}$ seedling ${ }^{-1}$.

To determine the carbohydrate content (free sugar and water soluble polysaccharides), $1 \mathrm{~g}$ of seeds was macerated with liquid nitrogen, until a thin powder was obtained. The extraction process was carried out using the method described by Bielski \& Turner (1966). For quantitative analysis of carbohydrates, the phenol sulphuric method described by Dubois et al. (1956) was used.
All data were analyzed through analysis of variance, using the $\mathrm{F}$ test. In case of significant differences between the treatments, the Tukey test at $5 \%$ was applied (Banzatto \& Kronka 2006). For viable remaining seeds (dormants), the transformation was carried out using the root arc sine $(\mathrm{x} / 100)$, for statistical purposes.

\section{RESULTS AND DISCUSSION}

A significant interaction between periods of seed hydration and products used for priming was verified for germination speed index, emergence speed index and accelerated aging (Table 2).

The use of gibberellin for priming provided a higher germination speed, in relation to water (control), in the lower period. Dantas et al. (2001) obtained lower germination time in $U$. plantaginea seeds conditioned with $\mathrm{GA}_{3}\left(0.250 \mathrm{mmol} \mathrm{L}^{-1}\right)$, similarly to the results obtained in this study. The use of gibberellin in grasses stimulates the biosynthesis of the $\alpha$-amylase hydrolytic enzyme, which breaks the storage polysaccharide (starch) necessary for the germination metabolism.

The lower hydration period provided the seeds a rapid emergence speed, and the use of gibberellin in the lower hydration period caused the highest

Table 2. Effect of hydration period for priming on the germination and emergence speed indexes and accelerated aging of Urochloa brizantha seeds.

\begin{tabular}{|c|c|c|c|c|}
\hline \multirow{2}{*}{ Hydration period } & \multicolumn{4}{|c|}{ Agents used in priming } \\
\hline & Water (control) & Gibberellin & Sucrose & Antioxidant \\
\hline \multicolumn{5}{|c|}{ Germination speed index } \\
\hline Lower & $9.86 \mathrm{abB}^{\mathrm{A}}$ & $14.87 \mathrm{aA}$ & $12.24 \mathrm{abAB}$ & $14.54 \mathrm{aA}$ \\
\hline Median & $12.38 \mathrm{aA}$ & $12.33 \mathrm{aA}$ & $14.14 \mathrm{aA}$ & $12.83 \mathrm{aA}$ \\
\hline Higher & $8.16 \mathrm{bA}$ & $8.98 \mathrm{bA}$ & $10.39 \mathrm{bA}$ & $8.82 \mathrm{bA}$ \\
\hline CV (\%) & 14.04 & & & \\
\hline $\mathrm{F}$ & $3.00 *$ & & & \\
\hline \multicolumn{5}{|c|}{ Emergence speed index } \\
\hline Lower & $12.35 \mathrm{aA}$ & $13.25 \mathrm{aA}$ & $12.68 \mathrm{aA}$ & $12.61 \mathrm{aA}$ \\
\hline Median & $10.80 \mathrm{aAB}$ & $9.27 \mathrm{bB}$ & $12.23 \mathrm{aA}$ & $11 \mathrm{abAB}$ \\
\hline Higher & $8.15 \mathrm{bB}$ & $9.92 \mathrm{Bab}$ & $11.38 \mathrm{aA}$ & $10.36 \mathrm{bA}$ \\
\hline $\mathrm{CV}(\%)$ & 9.77 & & & \\
\hline $\mathrm{F}$ & $3.17 *$ & & & \\
\hline \multicolumn{5}{|c|}{ Accelerated aging (\%) } \\
\hline Lower & $82 \mathrm{aAB}$ & $88 \mathrm{aA}$ & $74 \mathrm{Ab}$ & $86 \mathrm{aA}$ \\
\hline Median & $79 \mathrm{aA}$ & $83 \mathrm{abA}$ & $82 \mathrm{aA}$ & $87 \mathrm{aA}$ \\
\hline Higher & $76 \mathrm{aA}$ & $76 \mathrm{bA}$ & $84 \mathrm{aA}$ & $80 \mathrm{aA}$ \\
\hline $\mathrm{CV}(\%)$ & 7.17 & & & \\
\hline $\mathrm{F}$ & $2.61 *$ & & & \\
\hline
\end{tabular}


rate, in relation to its application in other periods. These results are consistent with those by Aragão et al. (2001), who applied gibberellin ( $\mathrm{GA}_{3}$ at a dose of $\left.100 \mathrm{mg} \mathrm{L}^{-1}\right)$ in the substrate of super sweet corn seeds (Zea mays). They found an increased emergence speed index, when compared to the control (without gibberellin on the substrate).

By using gibberellin in priming, a higher tolerance to the stress caused by the artificial aging of hydrated seeds in the lower period was verified, with a gain of $12 \%$ in the germination rate for hydrated seeds, in the higher period (Table 2).

According to the results, as the hydration period advanced, the physiological potential of the seeds decreased, as it can be seen by the decline of germination and increase of sensitivity to heat stress. This decrease in the physiological potential is associated with an increase of sensitivity to drying, as the germination process advances. According to Bewley \& Black (1994), the seeds tolerance to desiccation gradually decreases over the germination stages.

There was no interaction between the studied factors, regarding the first germination count, total germination, seeds remaining from the germination test (viable and dead), first emergence count and total emergence (Table 3). For these variables, the factors were analyzed separately.

Lower and median hydration periods provided a greater percentage of germination and emergence at 7 days, in relation to the higher hydration period. A higher percentage of total germination was observed for hydrated seeds in the lower period $(88 \%)$, in relation to the ones hydrated in the higher period $(82 \%)$. These results indicate that the hydration of seeds by direct immersion without aeration, further from phase III of germination, provides better results for the physiological potential of U. Brizantha seeds.

In the higher hydration period, near the protrusion (growth), possibly the seeds were more conducive to factors that caused a lower percentage of germination, with a higher number of dormant seeds, in relation to the lower hydration period. Priming was carried out in direct immersion, in the absence of artificial aeration and without moving the soaking solution. Thus, the medium had little oxygen diffusion, because at hydration seeds increase their respiratory rate, requiring a higher concentration of oxygen in the seed, for the metabolic processes of carbohydrate oxidation. According to Marcos Filho (2015), the absence or lack of oxygen favors the ethanol production in the cells, and this product is toxic to normal metabolism.

Therefore, the longer periods of hydration without aeration may affect the cell metabolism, because of the low performance of aerobic respiration. Respiration provides a greater amount of free energy for the production of higher amounts of protoplasm and cell wall, for the germination process, in addition to the production of secondary compounds that stimulate other metabolic pathways.

Gibberellin, which is a plant hormone that promotes seed germination (Cardoso 2013), did not increase the germination rate. Corroborating this result, Batista et al. (2015) and Cardoso et al. (2015)

Table 3. Effect of hydration period and priming agents on the first germination count (FGC), total germination (TG), viable and unviable seeds remaining from the germination test, first emergence count (FEC) and total emergence (TE) of Urochloa brizantha seeds.

\begin{tabular}{llllccc}
\hline \multirow{2}{*}{ Hydration period } & \multicolumn{2}{c}{ Germination } & \multicolumn{2}{c}{ Remaining seeds (\%) } & \multicolumn{2}{c}{ Emergence (\%) } \\
\cline { 2 - 7 } Lower & FGC & TG & Viable & Unviable & FEC & TE \\
Median & $82 \mathrm{a}^{\mathrm{A}}$ & $88 \mathrm{a}$ & $1 \mathrm{~b}$ & 11 & $80 \mathrm{a}$ & 83 \\
Higher & $82 \mathrm{a}$ & $86 \mathrm{ab}$ & $2 \mathrm{ab}$ & 12 & $80 \mathrm{a}$ & 83 \\
\hline Agents used in priming & $72 \mathrm{~b}$ & $82 \mathrm{~b}$ & $5 \mathrm{a}$ & 13 & $73 \mathrm{~b}$ & 79 \\
Water (control) & & & & & \\
Gibberellin & 80 & 88 & 3 & $7 \mathrm{~b}$ & $73 \mathrm{~b}$ & $78 \mathrm{~b}$ \\
Sucrose & 77 & 83 & 1 & $14 \mathrm{a}$ & $85 \mathrm{a}$ & $88 \mathrm{a}$ \\
Antioxidant & 78 & 85 & 2 & $11 \mathrm{ab}$ & $77 \mathrm{~b}$ & $81 \mathrm{~b}$ \\
\hline \multirow{2}{*}{ Priod } & 81 & 85 & 3 & $9 \mathrm{ab}$ & $75 \mathrm{~b}$ & $80 \mathrm{~b}$ \\
\hline Priming & $10.74^{* *}$ & $4.37^{*}$ & $9.05^{* *}$ & $0.53^{\text {ns }}$ & $4.95^{*}$ & $2.38^{\text {ns }}$ \\
\hline CV $(\%)$ & $0.74^{\text {ns }}$ & $1.784^{\text {ns }}$ & $1.47^{\text {ns }}$ & $4.42^{* *}$ & $6.71^{* *}$ & $5.50^{* *}$ \\
\hline
\end{tabular}

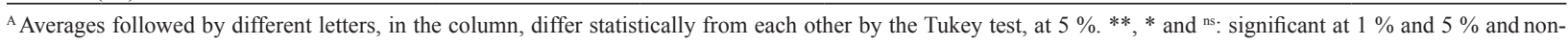
significant, respectively. 
found that the use of gibberellin for priming seeds at $50 \mathrm{mg} \mathrm{L}^{-1}$ and $0.5 \mathrm{mg} \mathrm{L}^{-1}$, respectively, did not influence the germination and emergence of $U$. brizantha $\mathrm{cv}$. MG-5 seeds. However, Silva et al. (2013) found an increase in the germination of $U$. brizantha $\mathrm{cv}$. Marandu and MG-5 seeds, when using $62.14 \mathrm{mg} \mathrm{L}^{-1}$ and $56.87 \mathrm{mg} \mathrm{L}^{-1}$ of gibberellin, respectively. Vieira et al. (1998) point out the gibberellin acid as the most effective substance for breaking dormancy in $U$. brizantha seeds. However, the authors did not observe the maximum germination, granting it to some additional factor that is related to the overcoming of seed dormancy. In this study, gibberellin positively influenced the emergence, providing benefits to the $U$. brizantha $\mathrm{cv}$. MG-5 seeds, evidenced by the increase in the number of emerged seedlings, in relation to other agents in the priming (Table 3 ).

There was no interaction between hydration periods and substances used for priming, regarding the seedlings dry phytomass and carbohydrates content in the seeds (Table 4). For these variables, the factors were analyzed separately.

A higher seedling dry phytomass with seed hydration was verified for the lower period. Regarding the substances tested, sucrose provided higher values, in relation to gibberellin (Table 4). The highest seedlings dry phytomass from hydrated seeds with sucrose occurred because it is a carbohydrate, which is an essential molecule for plant growth (Eveland \& Jackson 2012). The sucrose breakdown generates fructose and glucose, which influence directly the glycolytic pathway for energy production and secondary compounds for plant metabolism that can influence growth. According to Nelson \& Cox (2011), sucrose helps to provide the chemical energy necessary for the initial plant growth.

In relation to the carbohydrate content of $U$. brizantha seeds, it was verified that the increase in the hydration period provided, incrementally, a greater amount of free sugars content. This can be explained by the longer time available for hydrolysis of the seed reserve tissue. Hydration is important to initiate the seed metabolism, which is reduced under low water content (Table 4).

The gradual increase of free sugar, as the hydration period advances, is due to the fact that the simplest carbohydrates (glucose and fructose hexoses) are required during the germination process for energy supply. Buckeridge et al. (2013) emphasize that, during germination, seeds use sucrose (glucose + fructose) and oligosaccharides of the raffinose series as the initial carbon source for respiration. Carbohydrates and the respiration process are important for the production of sugars, phytohormones and various hydrolytic enzymes.

The use of sucrose for priming provided the largest amount of free sugar and soluble polysaccharides in seeds, in relation to other agents, with $45.40 \mathrm{mg} \mathrm{g}^{-1}$ and $35.98 \mathrm{mg} \mathrm{g}^{-1}$, respectively. The sucrose solution used for priming caused an increase in the amount of free carbohydrates present in the seeds (Table 4).

The hydration of seeds with gibberellin also provided a higher content of free sugar in the seeds, if compared to the control (Table 4). This is the result of the starch break down present in the reserve tissue

Table 4. Seedling dry phytomass, amount of free sugar and soluble polysaccharides, according to the hydration period and priming in Urochloa Brizantha seeds.

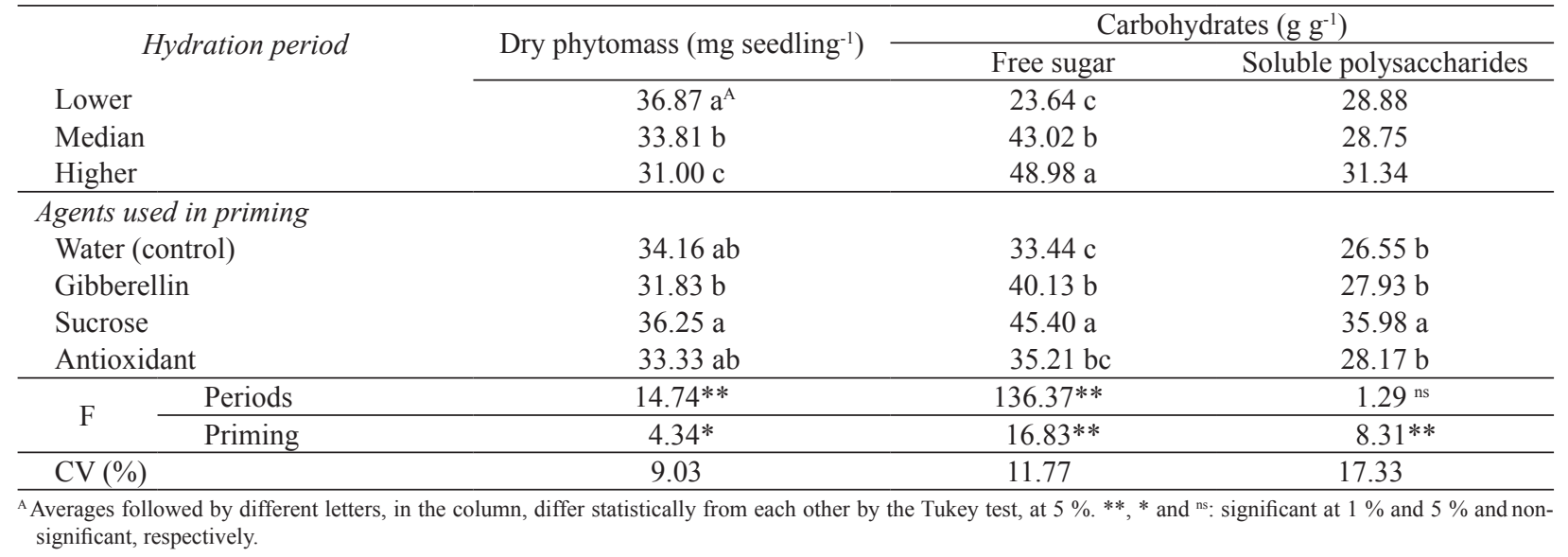


(endosperm), allowing a greater amount of free sugar. According to Guerra \& Rodrigues (2013), gibberellin induces the synthesis of hydrolytic enzymes, which act in the breaking of this reserve tissue. The largest free sugar content caused by immersion in a gibberellin solution, in relation to the control, may have resulted in a higher emergence of $U$. brizantha seedlings (Tables 3 and 4). This is consistent with findings by Aragão et al. (2003), which observed a higher activity of $\alpha$-amylase in super sweet corn seeds (Zea mays) pre-soaked in $\mathrm{GA}_{3}$ at $50 \mathrm{mg} \mathrm{L}^{-1}$, which provides an increase in germination and vigor.

\section{CONCLUSIONS}

1. The hydration of Urochloa brizantha seeds by direct immersion for a lower period of time (further from phase III of germination), without aeration, provides seeds with higher physiological potential;

2. The use of gibberellin in priming increases the seedlings emergence rate;

3. Sucrose application increases the carbohydrates concentration, during the germination of $U$. brizantha seeds.

\section{ACKNOWLEDGMENTS}

The authors thank the Conselho Nacional de Desenvolvimento Científico e Tecnológico (CNPq) and Fundação de Apoio ao Desenvolvimento do Ensino, Ciência e Tecnologia do Estado de Mato Grosso do Sul (Fundect), for the financial support (UNIVERSAL-MS, Process: 23/200.480/2014 and PIBIC/UEMS/Fundect).

\section{REFERENCES}

ARAGÃO, C. A. et al. Atividade amilolítica e qualidade fisiológica de sementes armazenadas de milho super doce tratadas com ácido giberélico. Revista Brasileira de Sementes, v. 25, n. 1, p. 43-48, 2003.

ARAGÃO, C. A. et al. Fitorreguladores na germinação e no vigor de plântulas de milho super doce. Revista Brasileira de Sementes, v. 23, n. 1, p. 62-67, 2001.

BANZATTO, D. A.; KRONKA, S. N. Experimentação agrícola. Jaboticabal: Funep, 2006.

BATISTA, T. B. et al. Nutrientes e giberelina no condicionamento fisiológico sob a qualidade de sementes de braquiária. Revista de Agricultura Neotropical, v. 2, n. 1, p. 10-16, 2015.
BATISTA, T. B. et al. Priming and stress under high humidity and temperature on the physiological quality of Brachiaria brizantha cv. MG-5 seeds. Acta Scientiarum Agronomy, v. 38, n. 1, p. 123-127, 2016.

BEWLEY, J. D.; BLACK, M. Seeds: physiology of development and germination. New York: Plenum Press, 1994.

BIELSKI, R. L.; TURNER, N. A. Separation and estimation of aminoacid in crude plant extracts by thin layer eletrophoreses and chromatography. Analytical Biochemistry, v. 17, n. 2, p. 278-282, 1966.

BINOTTI, F. F. S. et al. Tratamentos pré-germinativos em sementes de Brachiaria. Revista Brasileira de Ciências Agrárias, v. 9, n. 4, p. 614-618, 2014.

BONOME, L. T. et al. Efeito do condicionamento osmótico em sementes de Brachiaria brizantha cv. Marandu. Ciência e Agrotecnologia, v. 30, n. 3, p. 422-428, 2006.

BRASIL. Ministério da Agricultura, Pecuária e Abastecimento. Regras para análise de sementes. Brasília, DF: MAPA/ACS, 2009.

BUCKERIDGE, M. S. et al. Respiração. In: KERBAUY, G. B. (Ed.). Fisiologia vegetal. Rio de Janeiro: Guanabara Koogan, 2013. p. 150-164.

CARDOSO, E. D. et al. Desempenho fisiológico e superação de dormência em sementes de Brachiaria brizantha submetidas a tratamento químico e envelhecimento artificial. Semina: Ciências Agrárias, v. 35, n. 1, p. 2138, 2014.

CARDOSO, E. D. et al. Qualidade fisiológica e composição química de sementes de Brachiaria brizantha em função do condicionamento osmótico. Revista de Agricultura Neotropical, v. 2, n. 2, p. 42-48, 2015.

CARDOSO, V. J. M. Germinação. In: KERBAUY, G. B. (Ed.). Fisiologia vegetal. Rio de Janeiro: Guanabara Koogan, 2013. p. 384-408.

DANTAS, B. F. et al. Germinação de sementes de capim marmelada (Brachiaria plantaginea (Link.)) tratadas com ácido giberélico. Revista Brasileira de Sementes, v. 23, n. 2, p. 27-34, 2001.

DUBOIS, M. et al. Colorimetric method for determination of sugars and related substances. Analytical Chemistry, v. 28, n. 3, p. 350-356, 1956.

EVELAND, A. L.; JACKSON, D. P. Sugars, signalling, and plant development. Journal of Experimental Botany, v. 63, n. 9, p. 3367-3377, 2012.

GUERRA, M. P.; RODRIGUES, M. A. Giberelinas. In: KERBAUY, G. B. (Ed.). Fisiologia vegetal. Rio de Janeiro: Guanabara Koogan, 2013. p. 235-254. 
LARA, T. S. et al. Potassium nitrate priming affects the activity of nitrate reductase and antioxidant enzymes in tomato germination. Journal of Agricultural Science, v. 6, n. 2 , p. $72-80,2014$.

MAGUIRE, J. D. Speed of germination aid in selection and evaluation for seedling and vigour. Crop Science, v. 2, n. 2, p. 176-177, 1962.

MARCOS FILHO, J. Fisiologia de sementes de plantas cultivadas. Londrina: Abrates, 2015.

NELSON, D. L.; COX, M. M. Princípios de bioquímica de Lehninger. Porto Alegre: Artmed, 2011.

OLIVEIRA, A. B. et al. Qualidade fisiológica de sementes de algodão submetidas ao condicionamento osmótico e secagem. Revista Brasileira de Ciências Agrárias, v. 5, n. 3, p. 358-363, 2010.

OLIVEIRA, A. B.; GOMES-FILHO, E. Efeito do condicionamento osmótico na germinação e vigor de sementes de sorgo com diferentes qualidades fisiológicas. Revista Brasileira de Sementes, v. 32, n. 3, p. 25-34, 2010.

PESKE, F. B.; NOVEMBRE, A. D. L. C. Condicionamento fisiológico de sementes de milheto. Revista Brasileira de Sementes, v. 32, n. 4, p. 132-142, 2010.
QUEIROGA, V. P. et al. Qualidade fisiológica de sementes de algodoeiro submetidas ao condicionamento mátrico e osmótico. Revista Ceres, v. 58, n. 1, p. 56-61, 2011.

SILVA. A. B.; LANDGRAF, P. R. C.; MACHADO, G. W. O. Germinação de sementes de braquiária sob diferentes concentrações de giberelina. Semina: Ciências Agrárias, v. 34, n. 2, p. 657-662, 2013.

SOLTANI, E.; SOLTANI, A. Meta-analysis of seed priming effects on seed germination, seedling emergence and crop yield: Iranian studies. International Journal of Plant Production, v. 9, n. 3, p. 413-432, 2015.

TOKLU, F. Effects of different priming treatments on seed germination properties, yield components and grain yield of lentil (Lens culinaris Medik.). Notulae Botanicae Horti Agrobotanici Cluj-Napoca, v. 43, n. 1, p. 153-158, 2015.

VIEIRA, H. D.; SILVA, R. F.; BARROS, R. S. E. Efeito de substâncias reguladoras de crescimento sobre a germinação de sementes de braquiarão cv. Marandu. Revista Brasileira de Fisiologia Vegetal, v. 10, n. 2, p. 143-148, 1998. 